\title{
A Radiometrically Dated Record of Antarctic Ice Sheet Response to Millennial-Scale Climate Cycles during Glacials and Interglacials
}

Gavin Piccione ( $\nabla$ gpiccion@ucsc.edu )

University of California Santa Cruz https://orcid.org/0000-0002-7637-9796

\section{Terrence Blackburn}

Santa Cruz

Slawek Tulaczyk

University of California, Santa Cruz https://orcid.org/0000-0002-9711-4332

Troy Rasbury

Stony Brook University https://orcid.org/0000-0003-0591-4461

\section{Mathis Hain}

University of California, Santa Cruz https://orcid.org/0000-0002-8478-1857

\section{Daniel Ibarra}

Brown University https://orcid.org/0000-0002-9980-4599

\section{Katharina Methner}

Senckenberg https://orcid.org/0000-0002-3753-8256

Chloe Tinglof

University of California Santa Cruz

Brandon Cheney

University of California Santa Cruz

\section{Paul Northrup}

Kathy Licht

Indiana University-Purdue University

\section{Article}

\section{Keywords:}

Posted Date: February 11th, 2022

DOI: https://doi.org/10.21203/rs.3.rs-1300507/v1

License: (c) (i) This work is licensed under a Creative Commons Attribution 4.0 International License. 
Version of Record: A version of this preprint was published at Nature Communications on September 15th, 2022. See the published version at https://doi.org/10.1038/s41467-022-33009-1. 

Millennial-Scale Climate Cycles during Glacials and Interglacials

Authors: G. Piccione ${ }^{1 *}$, T. Blackburn ${ }^{1}$, S. Tulaczyk ${ }^{1}$, E.T. Rasbury ${ }^{2}$, M. Hain ${ }^{1}$, D.E. Ibarra ${ }^{3,4}$, K.

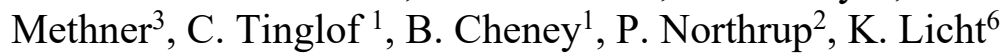

${ }^{1}$ Earth and Planetary Sciences, University of California Santa Cruz, Santa Cruz, CA 95064, USA

${ }^{2}$ Department of Geosciences, Stony Brook University, Stony Brook, NY 11794, USA.

${ }^{3}$ Department of Earth and Planetary Science, University of California Berkeley, CA 94720 USA

${ }^{4}$ Department of Earth, Environmental and Planetary Science, and the Institute at Brown for Environment and Society, Brown University, Providence, RI 02912, USA

${ }^{5}$ Department of Geological Sciences, Stanford University, Stanford, CA 94305, USA

${ }^{6}$ Department of Earth Sciences, Indiana University-Purdue University Indianapolis, IN 46202, USA

*Correspondence to: gpiccion@ucsc.edu

Records of changing ice mass in offshore sediments and ice cores suggest that the West Antarctic ice sheet experienced millennial-scale ice loss during the last termination. However, the distal location and short temporal coverage of these records leads to uncertainty in both the spatial footprint of ice response, and whether this response persists outside of glacial terminations. Here we present a $>100 \mathrm{kyr}$ archive of episodic Antarctic ice sheet basal melt events recorded by mineralogic variation in subglacial precipitates. ${ }^{234} \mathrm{U}$ ${ }^{230} \mathrm{Th}$ dates for two precipitates are used to build a time series of 32 opal-calcite transitions that correspond to Late Pleistocene millennial-scale climate cycles, with precipitation of opal during cold periods and calcite during warm periods. Geochemical data indicate that opal precipitation occurs via cryoconcentration of silica in brines beneath the ice sheet margin, while calcite precipitation is triggered by the addition of subglacial meltwater originating from the ice sheet interior. These freeze-flush cycles represent changes in subglacial hydrologic-connectivity driven by ice sheet velocity fluctuations, which likely occur in response to Southern Ocean thermal forcing acting on grounding lines within the Ross Embayment. Our results suggest that oscillating temperatures in the Southern Ocean affect the mass of the Antarctic ice sheet by regulating the delivery of heat to buttressing ice shelves and grounding lines on millennial timescales, regardless of the background climate state.

One of the persistent challenges involved in both reconstructions and projections of future global mean sea level is determining what sectors of the Antarctic Ice Sheet (AIS) are vulnerable to significant retreat, the timescales of such retreat, and the conditions that trigger retreat ${ }^{1}$. Modern observations ${ }^{2-4}$ of ice loss near marine-terminating ice sheet margins demonstrate the potential for rapid AIS mass fluctuations brought on by changing Southern Ocean (SO) temperature ${ }^{5}$ (hereafter referred to as ocean thermal forcing). The key link between this ocean thermal forcing and ice sheet mass lies in the delivery of heat to the marineterminating ice sheet margins, affecting ice shelves and grounding lines. Ice sheet stability is regulated by ice shelves ${ }^{6,7}$ and grounding line positions ${ }^{8}$, which are vulnerable to thinning and retreat when contacted by warm ocean waters. Ice sheet models suggest that ice shelf decay can result in enhanced flow of grounded 
ice up to $1000 \mathrm{~km}$ upstream of the grounding lines of large and fast outlet glaciers and ice streams ${ }^{9}$. On millennial timescales this feedback can cause substantial velocity changes in these fast-flowing ice drainage pathways ${ }^{10}$, ultimately affecting continent-wide ice sheet mass balance ${ }^{11}$.

Such millennial-scale SO temperature oscillations are driven by a feedback between oceanatmosphere-cryosphere teleconnections that is modulated by Atlantic Meridional Overturn Circulation $(A M O C)^{12}$ : the mean state ocean circulation responsible for cross-equatorial heat transport from the Southern Hemisphere to the Northern Hemisphere ( $\mathrm{SH}$ and NH). Changes to the intensity of AMOC result in out-of-phase polar temperature cycles ${ }^{13}$ recorded by isotopic climate proxies in ice cores, identified as Dansgaard-Oeschger cycles in the Greenland ice core records and Antarctic Isotope Maxima (AIM) events in Antarctic ice core records. For example, during times of decreased AMOC or slow northerly transport of heat, the $\mathrm{SH}$ temperature increases at the expense of the $\mathrm{NH}$, which is manifested as an increase in the $\delta^{18} \mathrm{O}$ composition in Antarctic ice cores and a decrease in $\delta^{18} \mathrm{O}$ composition in Greenland ice cores (e.g., 48 to $47 \mathrm{ka}$ in figure 1f, g). As AMOC recovers the $\mathrm{NH}$ temperature warms rapidly on decadal timescales while the SH gradually cools (e.g., at $46.7 \mathrm{ka}$ in figure $1 \mathrm{f}, \mathrm{g}$ ). This oceanic teleconnection, called the bipolar seesaw, also affects atmospheric circulation by regulating the temperature gradient between the middle and high latitudes ${ }^{14}$, which shifts the intertropical convergence zone (ITCZ) north during SH cold periods and south during SH warm periods. As the ITCZ migrates southwards during AIM events, SH westerly winds experience parallel meridional shifts and strengthening ${ }^{15}$, causing upwelling of relatively warm circumpolar deep waters $(\mathrm{CDW})$ onto the Antarctic continental shelf ${ }^{16}$. Consequently, reconstructions of Pleistocene SO temperatures ${ }^{17}$ demonstrate millennial warm-cold cycles in sea surface temperatures (SST) that are in-phase with ice core records of SH climate. Antarctic marginal ice is affected by these upwelling cycles, which deliver CDW to the base of ice shelves and grounding lines, triggering enhanced basal melting and retreat during SH millennial warm periods ${ }^{5}$.

Although ice sheet models $\mathrm{s}^{10,18}$ and modern observations $\mathrm{s}^{2-4}$ indicate that the AIS is susceptible to ice loss through ocean thermal forcing, regional differences in ice bed topography, drainage geometry, and ice thickness ${ }^{19}$ in peripheral sectors of Antarctica may lead to geographic differences in grounding line vulnerability, adding spatiotemporal complexity to ice sheet response. Millennial-scale SO upwelling also varies in intensity depending on the background climate state, with the slowest AMOC causing increased SO upwelling during glacial terminations, and relatively strong AMOC resulting in weaker SO upwelling during interglacial periods $\mathrm{s}^{20,21}$. Therefore, geologic evidence of AIS evolution across a wide geographic range and diverse climate states is necessary to ground truth simulations of suborbital changes in ice mass. However, existing geologic records documenting millennial-scale AIS mass $\operatorname{loss}^{22-24}$ are limited to bipolar seesaw events during the last two glacial terminations, are constrained by low-resolution age models, and are restricted spatially to ice shelf systems and offshore sediments. This leaves the regional extent and magnitude of AIS response to suborbital climate change unconstrained. Here, we present observations from an archive of subglacial hydrologic evolution recorded by chemical precipitates that formed $>900 \mathrm{~km}$ apart beneath the EAIS over a combined $>100 \mathrm{kyr}$ period during the Pleistocene. This dataset provides a novel sequence of high-resolution U-series age constraints on ice sheet evolution in response to millennial-scale climate change. Mineralogic and geochemical variations in subglacial precipitates provide evidence for basal hydrologic changes that are correlated with bipolar seesaw-related SH climate cycles. Combining precipitate data with a reduced-complexity model of ice sheet thermodynamics, we demonstrate a link between subglacial hydrologic conditions and millennial-scale changes in ice sheet velocity.

\section{RESULTS}

\section{Changes in Subglacial Precipitate Mineralogy Correlated with Millennial Climate Cycles}

In this study, we report geochronological and geochemical results collected from two subglacial precipitates: PRR50489, which formed in the David Glacier catchment and was collected at Elephant Moraine; and MA113, which formed beneath ice feeding Law Glacier and was collected at Mount Achernar moraine (Fig. 2). These samples were precipitated over tens of thousands of years in subglacial aqueous systems on the EAIS side of the Transantarctic Mountains (TAM), and were subsequently eroded and 
moraines $^{25}$. PRR50489 and MA113 are 3 and $9 \mathrm{~cm}$ thick respectively, with alternating layers of calcite and opal (Extended Data Fig. 1) implying cyclic change in the subglacial environment.

We measured ${ }^{234} \mathrm{U}_{-}{ }^{230} \mathrm{Th}$ ages on eleven opal layers from PRR50489 that constrain the timeframe of precipitation from 230 to $147 \mathrm{ka}$ (Fig. 1i), and ten opal and calcite layers from MA113 ranging in age from 55 to $42 \mathrm{ka}$ (Fig. 1f). We construct a stratigraphic age model for each sample using a Bayesian Markov chain Monte Carlo model in which the principal of superposition is imposed on each dated layer to refine age estimates based on stratigraphic $\operatorname{order}^{26}$ (Extended Data Fig. 2). Depth profiles of $\mathrm{Si}$ and $\mathrm{Ca}$ concentration collected using Energy Dispersive X-ray Spectroscopy provide a continuous representation of sample mineralogy: with high $\mathrm{Ca}$ areas representative of calcite and low $\mathrm{Ca}$ areas representative of opal. We pair stratigraphic age models with $\mathrm{Ca}$ concentration spectra to create timeseries describing the oscillations of precipitate mineralogy (Fig. 1a,d). These mineralogic timeseries reveal a temporal cyclicity in opal deposition, with opal layers in PRR50489 precipitated every 8-10kyr between marine isotope stages (MIS) 7 and 6, and opal layers in MA113 precipitated every 2-4kyr during MIS 3 (Fig. 1a, d). To investigate a possible link between cycles of precipitate mineralogy and climate, we compare mineralogic timeseries for each precipitate with climate proxies in both Antarctic ${ }^{27,28}$ (Fig. 1b,e,f) and Greenland ${ }^{29}$ (Fig. 1g) ice cores. Comparison between Ca-spectra and Antarctic temperature proxies reveals a highly regular linear relationship between climate cycles and precipitate mineralogy, with calcite formation (high $\mathrm{Ca}$ wt\%) during warm AIM peaks, and opal formation (low Ca wt\%) during Antarctic cold periods (Fig. 1). Moving window correlation calculations between MA113 and PRR50489 mineralogic spectra and SH climate proxies from Antarctic ice core records demonstrate a significant temporal correlation between the two records throughout the sampling period (Extended Data Fig. 3). This synchrony indicates that bipolarseesaw-driven climate change trigger variability in EAIS basal environments.

\section{Millennial-Scale Cycles in Subglacial Hydrologic Connectivity}

To understand the link between ocean-atmosphere-cryosphere teleconnections and the mineralogic composition of subglacial precipitates, we first utilize geochemical and isotopic measurements to characterize the provenance of opal and calcite source fluids. The carbon and oxygen isotopic compositions $\left(\delta^{18} \mathrm{O}_{\text {vsmow }}\right.$ ) of opal and calcite forming waters are distinct for both PRR50489 (Fig. 3a) and MA113 (Fig. $3 \mathrm{~b}$ ), with calcites forming from waters with extremely depleted $\delta^{18} \mathrm{O}$, and opals forming from waters with $\delta^{18} \mathrm{O}$ values up to $7 \%$ more enriched. The depleted $\delta^{18} \mathrm{O}$ compositions of the calcite endmember suggest origination of meltwaters generated beneath the EAIS interior ${ }^{30,31}$, as similarly depleted $\delta^{18} \mathrm{O}$ values are found only in ice from the high polar plateau ${ }^{32}$. The heaviest $\delta^{18} \mathrm{O}$ compositions of the opal endmember fluid (-46.15\% for PRR50489 and $-52.10 \%$ for MA113) are similar to the $\delta^{18} \mathrm{O}$ of ice proximal to the region where samples were exhumed ${ }^{31,33}$, suggesting that these waters originate as meltwater from marginal ice. Another distinguishing characteristic of opal and calcite forming waters are their cerium anomalies $\left(\mathrm{Ce}^{*}\right)$, a proxy for redox conditions ${ }^{34}$ (Fig. 3; Extended Data Fig. 4c). In both samples, Ce* correlates with sample mineralogy, with calcite $\mathrm{Ce} *$ values indicating precipitation from oxidizing waters $\left(\mathrm{Ce}^{*}<1\right)$, while the most ${ }^{18} \mathrm{O}$ enriched opals exhibit $\mathrm{Ce}^{*}$ values indicating precipitation from reduced waters $\left(\mathrm{Ce}^{*}>1\right)$ (Fig. 3; Extended Data Fig. $4 c$ ). In most cases, $\delta^{18} \mathrm{O}$ values of opal scale with $\mathrm{Ce}^{*}$, pointing to mixing between oxidized and reducing water during the formation of both minerals (Fig. 3a,b). Depleted $\delta^{13} \mathrm{C}$ compositions (-23\% for PRR 50489 and $-18 \%$ for MA113) of calcite forming waters imply that their carbon is sourced from subglacial organic matter that is oxidized during microbial respiration, consistent with observations from other EAIS basal aqueous systems ${ }^{35}$.

Calcite layers in both precipitates exhibit trends in $\delta^{13} \mathrm{C}$ and $\delta^{18} \mathrm{O}$ compositional space that suggest mixing between two isotopically distinct fluids with different carbon concentrations (Fig 3). To match the trends in the calcite data for PRR50489 and MA113, the $\delta^{13} \mathrm{C}$ and $\delta^{18} \mathrm{O}$ depleted, endmember calcite forming water must have 40 -fold and 5 -fold higher of the total carbon concentration respectively, relative to the low-carbon endmember opal forming water. Though $\delta^{13} \mathrm{C}$ of the opal forming water cannot be directly measured, for the mixing curve to fit calcite compositions and opal $\delta^{18} \mathrm{O}$ values requires the opal forming endmember to be isotopically heavy $\left(\delta^{13} \mathrm{C}>-5 \%\right.$ ): a composition comparable to that of sub-AIS brines ${ }^{36,37}$. Similar mixing relationships are observed between the ${ }^{87} \mathrm{Sr} /{ }^{86} \mathrm{Sr}$ and $\delta^{18} \mathrm{O}$ composition of opals and calcite 
(Fig. 3c,d), requiring endmember waters to be distinct in both $\mathrm{Sr}$ concentration and isotopic composition. In both samples, the opal forming waters have more radiogenic (higher) ${ }^{87} \mathrm{Sr} /{ }^{86} \mathrm{Sr}$ and heavier $\delta^{18} \mathrm{O}$ than the calcite forming waters. Sr:O mixing curves show that 20 -fold and 50 -fold of the total $\mathrm{Sr}$ in the system originates in the opal forming endmember (Fig. 3c, d). Due to their similar geochemical behavior, strontium and calcium concentrations in saline waters scale proportionally ${ }^{38}$. On this basis, the two endmember fluids must have distinctive $\mathrm{Ca}$ concentrations, with the opal forming endmember accounting for $>95 \%$ of $\mathrm{Ca}$ in the system. This mixing relationship affirms the prevalence of two endmember waters with divergent concentrations: a highly Ca-rich opal forming brine that dominates the aqueous cation budget, and a relatively $\mathrm{Ca}$-dilute, calcite forming meltwater that adds oxygen and carbon to the system.

Together, redox and isotopic data permit the identification of suitable analogs for both endmember waters. The opal endmember is characterized by low carbon and high calcium concentrations, an $\delta^{13} \mathrm{C}$ enriched composition, a $\delta^{18} \mathrm{O}$ composition that matches ice proximal to the TAM, and a $\mathrm{Ce}^{*}$ value indicative of reducing fluids, supporting the idea that opal precipitated from a subglacial brine with limited access to oxygen. A potential analog for opal forming waters are $\mathrm{CaCl}_{2}$ brines that emanate from beneath the modern EAIS in the McMurdo Dry Valleys (MDV) ${ }^{39}$. In addition to the aforementioned similarities between the opal endmember and MDV brines, the REE (Extended Data Fig. 5) and $\delta^{234} U_{o}$ (Table S1) of MDV brines ${ }^{40,41}$ match opal compositions measured in our subglacial precipitates, and X-Ray florescence microprobe images show high abundance of $\mathrm{Cl}^{-}$in opal layers (Extended Data Fig. 6). In comparison, the calcite endmember water has high carbon and low calcium concentrations, extremely depleted $\delta^{13} \mathrm{C}$ and $\delta^{18} \mathrm{O}$ compositions, and a $\mathrm{Ce} *$ signature indicative of oxidizing fluids. Combined, these geochemical signatures support a water composition analogous to glacial meltwater originating beneath the interior domes of East Antarctica, which would form from waters with highly depleted, oxygen-rich meltwater from dome-ice, can have high concentrations of depleted carbon from microbial respiration ${ }^{35,42}$, and would be much more dilute than marginal brines. Subglacial water measurements from the EAIS are few, but one candidate is C-rich, low salinity jökulhlaup water measured at Casey Station ${ }^{43}$ that flush from subglacial lakes beneath Law Dome, and like the precipitates studied here, resulted in subglacial calcite precipitation during an AIM warm period ${ }^{44}$. Based on the highly depleted $\delta^{18} \mathrm{O}$ values and the mixing relationships between the two endmember fluids, we can rule out other possible endmember waters including hydrothermal fluids, which have been proposed as the source for calcite precipitates from Boggs Valley, East Antarctica ${ }^{45}$, but would result in reduced $\mathrm{Ce}^{*}$ signatures, heavier $\delta^{18} \mathrm{O}$ and $\delta^{13} \mathrm{C}$ values, and lower $\delta^{234} U_{0}$ values. Finally, while it is possible that the observed range of $\delta^{18} \mathrm{O}$ values between opal and calcite result from compositional variations in basal ice local to the precipitate locations, evidence from mixing relationships, redox variations, and the consistent geochemical differences between opal and calcite waters across 32 mineral transitions (Fig. 3; Extended Data Fig. 4) support the idea that the two minerals formed in distinct waters from the EAIS margin and interior respectively.

To test if endmember mixing is a plausible mechanism for the observed opal and calcite layers, we use the frezchem database ${ }^{39}$ within the geochemical program PHREEQC ${ }^{46}$ to simulate geochemical mixing of the two endmember waters identified in the above-mentioned analyses (see Methods for full description of PHREEQC models). Monomineralic opal layers represent periods of amorphous Si saturation, which can occur in subglacial environments through cryoconcentration ${ }^{47,48}$. Extended Data figure 7 shows a set of PHREEQC simulations that demonstrate opal saturation during freezing of a $\mathrm{CaCl}_{2}$ brine, while the deficiency of carbon in the brine precludes calcite precipitation. Since geochemical data suggest calcite precipitation from an oxidized, carbon-rich, and isotopically distinct glacial meltwater, we explore conditions under which calcite saturates upon mixing with plausible compositions of EAIS basal meltwater with $\mathrm{CaCl}_{2}$ brine. Mixing the Casey Station jökulhlaup water with opal-forming brines, we identify a strong supersaturation in calcite over a broad range of mixing proportions (Extended Data Fig. 8), and a cessation of opal precipitation consistent with discrete calcite pulses during mixing. This model predicts that calcite precipitation occurs immediately upon addition of meltwater to brine, while there could be a significant lag in opal precipitation as the aqueous system transitions back to basal freezing and cryoconcentration. Indeed, we may be seeing the effects of this lag in the temporal comparison between climate cycles and precipitate mineralogy, where nearly all warming events have a corresponding calcite layer (e.g., 180 and 190ka), 
while some particularly short-lived cold events ( $<4 \mathrm{kyr}$ duration) do not have a detectable corresponding opal layer (e.g.,163 and $173 \mathrm{ka})$.

\section{Millennial-Scale Ice Sheet Thickness Changes Driven by Ocean Thermal Forcing}

The key finding from our subglacial precipitate archive is that millennial-scale ocean-atmospherecryosphere teleconnections cause a hydrologic response beneath the EAIS, where AIM warm phases drive enhanced delivery of subglacial meltwater from the interior to the ice sheet margin. Subsequent millennial cold phases then promote expansion of basal freezing causing the subglacial aqueous system near the ice sheet edge to become hydrologically isolated from the ice sheet interior. We investigate how millennial climate cycles may lead to shifts in subglacial hydrologic connectivity using a reduced complexity model of ice sheet thermodynamics, which simulates the evolution of basal melting and freezing rates in response to climate forcing (see supplementary text for full description). Our model framework assumes that ice thickness at the foothills of the TAM, which is by itself driven by the position of the grounding line in the Ross Embayment, is a linear function of the isotopic records of climate from either EDC (PRR50489) or WDC (MA113) ice cores (Fig. $1 \mathrm{~b}, \mathrm{f}$ ). Changing ice thickness feeds into variations in ice surface slope, basal shear stress, ice velocity, and basal shear heating, which affect the subglacial heat budget in the TAM. Calculated basal freezing/melting rates in the two inferred regions of sample formation provide a satisfactory match to the radiometrically dated records of calcite and opal precipitation from PRR50489 and MA113 (Fig. 1c, i). This result is consistent with linear sensitivity of ice thickness in the Ross Embayment to the climatic variations reflected in isotopic ice core records from WAIS and EAIS, which are dominated by variability in ocean conditions with additional impacts of atmospheric temperature changes ${ }^{49}$. Scaling laws for ice sheet volumes ${ }^{50}$ indicate a high sensitivity of ice volume to ice thickness changes, implying that the volume of AIS exhibited non-linear sensitivity to the millennial-scale climate forcing recorded in Antarctic ice cores. Collectively, our paired ice sheet thermodynamic simulations and precipitate record demonstrates that the ice on the EAIS side of the Ross Sea experiences significant thickness and volume fluctuations not only in response to large climate warming events during terminations, but also in response to climate cycles that are both smaller in amplitude and shorter in duration than major terminations, such as AIM events.

To produce basal freeze-melt cycles that are temporally correlated with precipitate opal-calcite transitions (Fig. 1c, i), our reduced complexity model of ice sheet thermodynamics requires changes to ice thickness on the order of hundreds of meters at the foothills of TAMs (e.g., near the mouth of the valley containing David Glacier for PRR50489) (Fig. S1, S2). Ice drawdown of a similar magnitude is observed in the Weddell Sea Embayment during post-LGM AIM events ${ }^{18,23}$, while models simulating AIS response to millennial-scale ocean-thermal forcing support the possibility of thickness change on this scale throughout the Pleistocene ${ }^{11}$. Our results imply that ice around the Ross Embayment exhibits a similarly high sensitivity to millennial-scale ocean thermal forcing during both glacial and interglacial background climate states. While our current dating uncertainties in AIS precipitates prevent us from determining whether ice response lags ocean forcing, the observed linear correlation between opal-calcite transitions and SH millennial climate cycles requires that ice thickness changes occurred at most, centuries after initial SO upwelling. Emerging models for the onset and duration of ice mass change in response to bipolar seesaw related climate cycles show similarly rapid ice loss events lasting centuries to millennial ${ }^{18}$.

\section{DISCUSSION}

The results presented here indicate that two chemical precipitates, separated by $\sim 900 \mathrm{~km}$ and deposited tens of thousands of years apart, form as a consequence of subglacial hydrologic cycles that match the patterns of SO and Antarctic climate changes recorded in ice cores, implying a link between AIS basal conditions and SH climate. More specifically, the site of precipitate formation oscillates between the freezing of local brines sourced from the proximity of the TAM during cold periods, and the influx of far field EAIS meltwaters during warm periods. Predictions of modern subglacial thermal conditions ${ }^{51,52}$ indicate that large portions of the EAIS are at, or near the pressure melting point, with widespread melting in the ice sheet interior. In areas on the ice sheet periphery, thinner ice provides less insulation from cold 
surface temperatures, resulting in basal freezing. Comparisons between simulations of modern basal melt rate $^{52}$ and precipitate collection sites (Fig. 2 b,c) show that both PRR50489 and MA113 are found within $10 \mathrm{~km}$ of the boundary between basal freezing and melting predicted by an ice sheet model with $5-\mathrm{km}$ horizontal resolution ${ }^{52}$. While the exact location of precipitate formation is unknown, several lines of evidence support their formation close to the collection site, and hence near the freeze-melt boundary. Specifically, dispersal of entrained sediment in basal ice follows a negative exponential decay law, making it far more likely for cobble-sized glacial sediments (PRR50489 and MA113 are 3 and 9cm thick) to originate within kilometers of the collection site rather than hundreds or thousands of kilometers ${ }^{53}$. The basal thermal regime also affects the likelihood of erosion and transport by the overlying ice, with the maximum degree of scouring and entrainment occurring in areas at the transition between basal melting upstream and basal freezing downstream ${ }^{54}$. Finally, both MA113 and PRR50489 are found in areas with very slow modern ice velocities ${ }^{25,55}$, which likely limits their transport distance to $<50 \mathrm{~km}^{31}$. We therefore propose that the cycles of basal melting and freezing indicated by opal-calcite precipitates are the result of migrations of the basal thermal and hydrologic boundary, causing changes in the connectivity between waters from the interior and edge of the ice sheet following millennial-scale climate cycles (Extended Data Fig. 9).

Based on our reduced complexity model of ice sheet thermodynamics, the most parsimonious explanation for changes in subglacial hydrologic connectivity is periodic acceleration of ice flow. The driving mechanism for ice sheet acceleration on these timescales is generally regarded to be grounding line migration stemming from subsurface melting of ice shelves ${ }^{56}$. During millennial cold periods, grounded ice advances towards the continental shelf edge. As the bipolar seesaw takes effect, the ocean-atmosphere teleconnection between slowing AMOC and strengthening SH westerly winds drives upwelling of relatively warm circumpolar intermediate waters ${ }^{49}$, which contact ice shelves and grounding lines. Ice shelf thinning reduces back stress and increases ice discharge across the grounding lines ${ }^{5}$, leading to gradual catchment-scale ice flow acceleration ${ }^{9}$. Corresponding ice thinning starts near grounding lines and propagates upstream, leading to steepening of surface slopes and increased driving and basal shear stress. Higher ice flow rates and basal stress boost basal shear heating, which causes enhanced basal melting and increased subglacial hydrologic connectivity. Proxy records for SO sea surface temperature ${ }^{17}$ and upwelling $^{21}$ provide evidence for millennial scale variations in-phase with the bipolar seesaw. Comparison between our subglacial precipitate record and SO sea surface temperature ${ }^{17}$ shows a similar pattern of millennial-scale variability (Fig.1h), supporting bipolar seesaw-driven SO thermal forcing changes as a mechanism for millennial-scale AIS volume changes. This finding has implications for assessment of future mass loss from Antarctica triggered by ongoing anthropogenic warming and for interpretation of distal evidence for sea-level high stands during Quaternary warm climate periods ${ }^{57}$.

The basal thermal regime of AIS outlet glaciers is highly complex, with models demonstrating along-flow transitions between frozen and unfrozen basal conditions resulting from variations in bed topography, ice thickness, and flow rate along the ice sheet path ${ }^{58}$. While we acknowledge that localized basal temperature change could affect precipitate mineralogy, the collective geochronological and geochemical dataset presented here strongly favors hydrologic cycles driven by regional, rather than local, ice response. The consistent relationship between subglacial transitions from freezing to melting recorded at two different locations requires a highly regular triggering mechanism that is linked to the cryosphere and to the broader climate system. On both a glacier and regional scale, fluctuations between basal freezing and melting in the regions immediately upstream of our sample locations necessitate a change in ice sheet velocity or thickness, as atmospheric temperature change could not propagate to the ice sheet base on millennial timescales (see supplementary text for detailed explanation). This requisite dynamic ice sheet response implicates ocean forcing as the likely mechanism for the observed millennial-scale subglacial hydrologic changes regardless of spatial extent. Based on the locations of the two chemical precipitates studied here, an ocean-cryosphere teleconnection must operate in two catchments that are separated by $\sim 900 \mathrm{~km}$ and are not glaciologically linked, pointing to embayment-wide ice shelf mass fluctuation on millennial timescales. Geochemical evidence for millennial-scale flushing of dome-like meltwaters to marginal locations (Fig. 3) suggests that ice sheet acceleration in response to ice shelf perturbation enhances 
hydrologic connectivity between subglacial waters separated by hundreds of kilometers. Given these spatiotemporal constraints, we conclude that opal-calcite transitions in subglacial precipitates result from millennial-scale migration of the regional freeze-melt boundary beneath grounded ice around the Ross Embayment.

Subglacial water has a significant effect on ice sheet motion, where ice sheet acceleration is often tied to the presence ${ }^{59}$, flushing ${ }^{60}$, and distribution ${ }^{61}$ of subglacial water systems. Yet, the interaction between ice sheet dynamics and long-term changes in the subglacial hydrologic system in Antarctica are virtually unconstrained, largely due to the here-to-fore missing records documenting their long-term climate sensitivity. Here we have presented data from subglacial precipitates that provide evidence for millennialscale acceleration of ice around the Ross Embayment, triggered by ocean thermal forcing. Our results show, for the first time, that the AIS responds to bipolar-seesaw related climate cycles regardless of the background climate state. Enhanced ice sheet velocity in the Ross Embayment causes hydrologic connectivity between the ice sheet interior and marginal regions. Added meltwater to previously frozen portions of the ice sheet can lubricate the bed and likely acts as feedback for further ice sheet acceleration and mass loss.

\section{METHODS}

\section{Subglacial precipitate opal-calcite timeseries}

Time series describing mineralogic shifts between opal and calcite in two subglacial precipitates are derived from ${ }^{234} \mathrm{U}_{-}{ }^{230} \mathrm{Th}$ ages combined with elemental characterization (see supplementary text for full ${ }^{234} \mathrm{U}_{-}{ }^{230} \mathrm{Th}$ dating methods). To construct the stratigraphic age model for each sample, we use a Bayesian Markov chain Monte Carlo model that considers the age of each layer and its stratigraphic position within the sample to refine the uncertainty of each date using a prior distribution based on the principal of superposition ${ }^{26}$. Elemental maps showing calcium and silicon concentration (Extended Data Fig. 2) were produced using Energy Dispersive X-ray Spectroscopy (EDS) measured on the Thermoscientific Apreo Scanning Electron Microscope (SEM) housed at UCSC. EDS data were generated using an Oxford Instruments UltimMax detector and were reduced using AZtecLive software. To quantify the opal-calcite transitions in the samples, Si and Ca concentration data were produced from line scans across precipitate layers (Extended Data Fig. 1). For sample MA113, detritus within two calcite layers results in Si peaks that do not correspond to opal. These areas are identified by high aluminium concentrations and are corrected to reflect a calcite composition. Timeseries in figure 1a and $1 \mathrm{~d}$ were then generated by plotting the stratigraphic age model, against $\mathrm{Ca}$ concentration spectra. Within the error bounds of our precipitate age models and the ice core climate records, we are not able to estimate sub-millennial leads or lags between the AIS response and climate cycles. Nonetheless, stratigraphic consistency between dated layers, the regular frequency of mean ages, and the significant correlation between our mineralogic timeseries and climate proxy records supports our conclusion of a link between climate teleconnections and subglacial hydrology. Furthermore, as was previously mentioned, calcite layers form rapidly upon introduction of carbon-rich, alkaline waters from the EAIS interior to the marginal system, and the system then slowly transitions back to opal precipitation after hydrologic connectivity is shut off and the waters freeze. Therefore, it is possible that there is missing time between calcite layers that is not accounted for in stratigraphic age models. However, based on the regularity of opal depositional cycles, and the similarity between precipitate opal-calcite cycles and climate proxies, these unconformities do not represent enough time to disrupt the millennial-scale cyclicity of the precipitate mineralogy.

Correlation between opal-calcite timeseries from both samples and ice core climate records is assessed both visually, by plotting stacked spectra, and by moving window correlation coefficient ${ }^{62}$ (Extended data Fig. 3). Although the link between subglacial hydrologic events and SH climate cycles is the result of a complex ocean-atmosphere-cryosphere feedback, stacked records reveal a clear overlap between the mineral transitions in precipitates and ice core climate proxies (Extended data Fig. 3a, c). Moving window Pearson $r$ correlation coefficients show a significant linear correlation between precipitate and SH climate timeseries for both samples. The one acceptation to this synchrony is in sample MA113 during the period between 54 and $50 \mathrm{ka}$. The lack of a clear relationship between the two records during 
this timeframe could be the result of dating uncertainties in both MA113 and the ice core records, or poor millennial-scale climate resolution in the WDC during this period. Indeed, inspection of the TDC between 54ka and 50ka shows small scale climate cycles that do not appear in WDC, and have a similar pattern to opal-calcite cycles in MA113 (Fig. 1d, e, f). Therefore, we find it likely that the three calcite peaks in MA113 correspond to the three small-scale warming events that appear in the TDC record.

\section{Stable Isotopic Analyses}

Carbonate isotope ratios $\left(\delta^{13} \mathrm{C}_{\mathrm{CO} 3}\right.$ and $\left.\delta^{18} \mathrm{O}_{\mathrm{CO} 3}\right)$ were measured by UCSC Stable Isotope Laboratory using a Themo Scientific Kiel IV carbonate device and MAT 253 isotope ratio mass spectrometer. Referencing $\delta^{13} \mathrm{C}_{\mathrm{CO} 3}$ and $\delta^{18} \mathrm{O}_{\mathrm{CO} 3}$ to VPDB is calculated by two-point correction to externally calibrated Carrara Marble 'CM12' and carbonatite NBS- $18^{63}$. Externally calibrated coral 'Atlantis $\mathrm{II}^{164}$ was measured for independent quality control. Typical reproducibility of replicates was significantly better than $0.05 \%$ for $\delta^{13} \mathrm{C}_{\mathrm{CO}}$ and $0.10 \%$ for $\delta^{18} \mathrm{O}_{\mathrm{CO} 3}$.

Opal layers were analyzed at the Stanford University Stable Isotope Biogeochemistry Laboratory for $\delta^{18} \mathrm{O}_{\mathrm{SIO} 2}$ by conventional $\mathrm{BrF}_{5}$ fluorination (e.g. refs. ${ }^{65,66}$ ) and measured with $\mathrm{O}_{2}$ gas as the analyte on a Thermo Scientific MAT 253+ dual-inlet isotope ratio mass spectrometer (IRMS) ${ }^{67,68}$. Briefly, 2-3 mg opal samples were loaded into nickel reaction tubes as described in ref. ${ }^{69}$ and heated for 2 hours at $250{ }^{\circ} \mathrm{C}$ at high vacuum. Samples were then repeatedly pre-fluorinated at room temperature with 30 mbar aliquots of $\mathrm{BrF}_{5}$ until $<1$ mbar of non-condensable gas was present. A 30x stoichiometric excess of $\mathrm{BrF}_{5}$ was added to the nickel tubes and sealed. The nickel tubes were then heated at $600{ }^{\circ} \mathrm{C}$ for 16 hours to quantitatively produce $\mathrm{O}_{2}$. The generated $\mathrm{O}_{2}$ gas is then sequentially released into the cleanup line, cryogenically cleaned and frozen onto a $5 \AA$ mole sieve trap immersed in liquid nitrogen, equilibrated at room temperature with the IRMS dual-inlet sample-side bellows and measured for $\delta^{18} \mathrm{O}$ against a reference tank of known $\delta^{18} \mathrm{O}$ composition (24.3\%o) (for details refs. ${ }^{68,69}$ ). Opal $\delta^{18} \mathrm{O}$ is reported based on daily corrections made to four primary silicate standards (NBS-28, UWG-2, SCO and L1/UNM_Q, which are quartz, garnet, olivine and quartz, respectively), spanning $13 \%$, and have been recently calibrated to the VSMOW2-SLAP2 scale ${ }^{66,70}$. Three secondary standards (BX-88 (Stanford Laboratory internal standard), UCD-DFS (obtained from H. Spero, UC Davis; values reported in ref. ${ }^{71}$ ) and PS1772-8 (obtained from J. Dodd, Northern Illinois University; measured at U. of New Mexico and reported in ref ${ }^{72}$, which are quartz, opal-CT and opal-A, respectively) were also analyzed over the course of the analyses. Replicate measurements of standards demonstrate reproducibility of $<0.3 \%$ for all secondary and primary standards except the PS1772-8 standard, though heterogeneity in this standard is suspected with laboratory averages reported in the literature $^{72}$ ranging from 40.2 to $43.6 \%$ (average value of $41.5 \%$ in this study).

\section{Sr Isotopic Analyses}

Sr isotopic measurements were made at the UCSC Keck Isotope Laboratory. Sr compositions are measured on a TIMS in a one sequence static measurement: ${ }^{88} \mathrm{Sr}$ is measured on the Axial Faraday cup, while ${ }^{87} \mathrm{Sr}$, ${ }^{86} \mathrm{Sr},{ }^{85} \mathrm{Rb}$, and ${ }^{84} \mathrm{Sr}$ are measured on the low cups. Accuracy of the ${ }^{87} \mathrm{Sr} /{ }^{86} \mathrm{Sr}$ measurements is evaluated using Sr standard SRM987 compared to a long-term laboratory average value of 0.71024 , with a typical reproducibility of \pm 0.00004 .

\section{LA ICP-MS Methods}

Laser ablation inductively coupled plasma-mass spectrometry (LA ICP-MS) analyses were conducted at the Facility for Isotope Research and Student Training (FIRST) at Stony Brook University. Analyses were made using a 213 UV New Wave laser system coupled to an Agilent 7500cx quadrupole ICP-MS. The National Institute of Standards and Technology (NIST) 612 standard was used for approximate element concentrations using signal intensity ratios. Laser data were reduced in iolite ${ }^{73}$; element concentrations were processed with the trace-element data reduction schemes (DRS) in semiquantitative mode, which subtracts baselines and corrects for drift in signal.

\section{Geochemical models of mineralogic cyclicity in subglacial precipitates:}


To understand the conditions under which discrete pulses of opal and calcite are precipitated following cold and warm Antarctic climate periods respectively, we integrate geochemical and isotopic characterization of the precipitates to inform simulations run using the aqueous geochemical modeling program PHREEQC ${ }^{46}$. The high ion concentrations of subglacial fluids necessitates the use of the Pitzer specific ion interaction approach, which allows PHREEQC to model the aqueous speciation and the mineral saturation index of brines, and has been shown to yield results ${ }^{39}$ consistent with the subzero database FREZCHEM ${ }^{74}$. Our modeling approach to simulating opal-calcite transitions can be describe in three parts: 1) Identify the water composition and conditions under which opal will precipitate and calcite will not; 2) Identify the composition and volume of water required to mix with opal forming fluids to produce calcite; 3) Utilize the $\delta^{18} \mathrm{O}$ and $\delta^{13} \mathrm{C}$ isotopic composition of calcite and opal, along with the known or inferred composition of mixing waters (Fig. 3) to constrain the relative volumes of brine and meltwater, thereby testing the validity of the mixing model. While the exact ionic strength of subglacial fluids and temperature of the subglacial aqueous system is unknown, we outline a plausible scenario for discrete layers of opal and calcite that fit modeled conditions at the base of the ice sheet ${ }^{51}$, and the geochemical constraints measured in precipitates.

\section{PHREEQC Simulations Part 1}

Opal precipitation occurs when a solution is saturated with respect to amorphous silica. Opal solubility is both temperature and $\mathrm{pH}$ dependent ${ }^{75}$, with lower $\mathrm{pH}$ favoring precipitation. The silicon concentrations of subglacial waters ${ }^{76}$ and mature brines that emanate from ice sheets ${ }^{77}$ are typically tens of ppm, - values similar to other surface waters ${ }^{78}$ - and Si concentration does not scale with total dissolved solids (TDS) ${ }^{79}$. At these relatively low Si concentrations, saturation of amorphous silica cannot be achieved without a mechanism to concentrate $\mathrm{Si}$ in solution. For aqueous systems beneath an ice sheet, this mechanism is very likely cryoconcentration via subglacial freezing, which extracts water from the cavity at the base of the ice sheet, concentrating solutes and raising mineral saturation ${ }^{48,80,81}$. Yet, most surface waters upon reaching saturation of amorphous silica will also be at saturation for calcite ${ }^{48,81}$, thus not matching the discrete opal layers observed in our precipitates. This suggests that the opals form from a mature brine ${ }^{79}$ that is relatively free of $\mathrm{HCO}_{3}^{-}$. A candidate fluid that fits these compositional criteria are $\mathrm{CaCl}_{2}$ brines, which occur in the McMurdo Dry Valleys (MDV) as shallow subsurface waters ${ }^{82-85}$, deep groundwaters ${ }^{39,84,86}$, and surface waters $^{87-89}$, most notably feeding Lake Vanda ${ }^{77,90}$ and Don Juan Pond(DJP) ${ }^{86,91,92}$. Ca-Cl-rich brines also occupy regions that were previously covered by the North American ${ }^{79}$ and Fennoscandian ice sheet ${ }^{93}$, implying that they are a natural product of fluid isolation beneath ice sheets. Therefore, $\mathrm{CaCl}_{2}$ brines are a plausible composition for brine beneath the EAIS. The most geochemically well characterized MDV brines are those that feed DJP, therefore, we explore opal precipitation by equilibrating DJP brine with ice, calcite, and opal at a range of temperatures between $-5^{\circ} \mathrm{C}$ to $5^{\circ} \mathrm{C}$. At full concentration, DJP brine causes melting of the overlying ice due to its exceptionally high ionic strength, resulting in significant dilution of the original solution, which inhibits opal precipitation (Extended Data Fig.7a). Subsequent simulations of 10x and 50x diluted DJP brine over the same range of temperatures result in a gradual increase of opal saturation due to the incremental removal of water via cryoconcentration (Extended Data Fig. 7b, c). In these model runs, opal precipitation is controlled by the amount of water removed from the solution by freezing, which itself is controlled by ionic strength. At 10x concentrated, the solution does not freeze enough to drive opal precipitation, while opal is precipitated from the $50 \mathrm{x}$ diluted solution between $-3^{\circ} \mathrm{C}$ and $-4^{\circ} \mathrm{C}$. A fourth PHREEQC model was run equilibrating DJP brine with ice, calcite, and opal over this temperature range, indicating that opal precipitation is reached once $\sim 75 \%$ of the water in the original solution is lost via freezing, which occurs at $-3.5^{\circ} \mathrm{C}$ (Extended Data Fig. $7 \mathrm{~d}$ ).

\section{PHREEQC Simulations Part 2}

Simulation of calcite precipitation during AIM warm periods assumes that 'meltwaters' are mixed with the concentrated 'glacial brines' from part 1 . The decision to model calcite precipitation using the admixture of new waters, rather than to reverse subglacial freezing, is based on the disparity in geochemistry between calcite and opal forming waters (Fig. 3; Extended Data Fig. 4). Based on the hypothesis that calcite layers form when waters from the EAIS interior are flushed to the ice sheet edge, meltwaters driving calcite 
precipitation are likely to have become enriched in alkalinity and dissolved ions through water-rock interaction and chemical weathering of silicate minerals in the substrate during long-term storage beneath the EAIS. Calcite and opal data in ${ }^{87} \mathrm{Sr}{ }^{86} \mathrm{Sr}$ vs $\delta^{18} \mathrm{O}$ space provide further evidence that the two endmember waters - brine and subglacial meltwater- dissolve silicates with different provenance. Figure $3 \mathrm{c}$ and $3 \mathrm{~d}$ show ${ }^{87} \mathrm{Sr}{ }^{86} \mathrm{Sr}$ vs $\delta^{18} \mathrm{O}$ mixing curve between opals and calcite, which indicate that the brine provides $98 \%$ of Sr to the system from a source with an ${ }^{87} \mathrm{Sr}{ }^{86} \mathrm{Sr}$ of 0.7135 , while the meltwater endmember has a far lower concentration of $\operatorname{Sr}(2 \%)$ derived from a reservoir with an ${ }^{87} \mathrm{Sr} /{ }^{86} \mathrm{Sr}$ of 0.709 . These data are consistent with a brine that weathers silicate minerals over long periods, and a meltwater that drives silicate weathering with a very different provenance over a relatively short time duration. The $\delta^{13} \mathrm{C}$ of the calcite $(-23 \%)$ (Fig. 3, Extended Data Fig. 4) also provides evidence for the chemical composition of meltwaters, implying that they accumulated carbon through microbial respiration, which does not fractionate during the transition from aqueous $\mathrm{CO}_{2}$ to $\mathrm{HCO}_{3}{ }^{-}$if $100 \%$ of the carbon undergoes this conversion. Given, the similarity between $\delta^{13} \mathrm{C}$ composition of calcite and that of respired carbon, it is unlikely that dissolution of sedimentary carbonates took place in the meltwater, which would have added a significantly less depleted source of carbon to the reservoir. This framework suggests that candidate compositions for calcite endmember fluids are waters with a similar history of subglacial exposure to glaciated sediments. The EAIS waters that best fit this description are jökulhlaup waters ${ }^{43}$ observed near Casey Station, Antarctica. Using PHREEQC, we explore mixing of brine from part 1 with jökulhlaup waters from Casey $\operatorname{Station}^{43}$, by simulating a range of possible mixing ratios between brine and meltwater. We infer, based on the Ca:Sr ratios from other surface water systems that contain $\mathrm{CaCl}_{2}$ brine, that the ratio of $\mathrm{Ca}$ concentration between the brine and meltwater matches the ratio of $\mathrm{Sr}$ concentration between the two fluids (brine:meltwater $=98: 2$ ). Results show that without at least $30 \%$ meltwater the mixture too diluted with respect to $\mathrm{Ca}$ and $\mathrm{HCO}_{3}{ }^{-}$to precipitate calcite. PHREEQC mixing models successfully produced discrete pulses of calcite with mixtures between $30 \%$ and $80 \%$ meltwater; conditions under which the admixture is undersaturated with respect to opal because the solution is too dilute with respect to $\mathrm{Si}$ and is supersaturated with respect to calcite leading to precipitation (Extended Data Fig. 8). Therefore, the addition of carbon-rich, alkaline meltwaters to opal precipitating, $\mathrm{Ca}-\mathrm{Cl}$-rich brines can trigger calcite supersaturation driving rapid calcite growth, consistent with our geochronologic outputs and calcite morphology. Collectively this modeling effort, along with the timescale data presented in figure 1, and the fibrous crystal textures, suggests that calcite forms rapidly after meltwaters are added to the subglacial aqueous system. However, the relative volume of meltwater added is unclear from these results alone and requires further isotopic constraints outlined below.

\section{$C$ and $O$ Isotopic Mixing Models Part 3}

For both the calcite and opal oxygen isotope data, the formation water $\delta^{18} \mathrm{O}$ (Fig. 3; Extended Data Fig. 4) is calculated using the appropriate equilibrium water-mineral fractionation factors assuming a temperature (T) of $0^{\circ} \mathrm{C}(273.15 \mathrm{~K})$. For calcite we use the empirical $1000 \ln \alpha$ versus $1 / \mathrm{T}$ relationship of ${ }^{94}$ and for opal the $1000 \ln \alpha$ versus $1 / \mathrm{T}^{2}$ relationship of ${ }^{95}$ for $\mathrm{T}$ in kelvin. The $1000 \ln \alpha$ values for calcite and opal are $33.6 \%$ and $44.2 \%$, respectively, and we calculate the formation waters avoiding the non-linearity associated with delta notation far from the standard of choice (in this case VSMOW). As such, we calculate the formation waters composition as: $\alpha=\left(1000+\delta^{18} \mathrm{O}_{\text {mineral }}\right) /\left(1000+\delta^{18} \mathrm{O}_{\text {water }}\right)$.

Calcite data, in $\delta^{13} \mathrm{C}$ vs $\delta^{18} \mathrm{O}$ space, define a trend that suggests they form through admixture with an isotopically lighter water with respect to both carbon and oxygen. The carbon concentration dependent mixing curve that best fits that calcite data alone requires that the isotopically light endmember, what we'll refer to here as the "meltwater" endmember carries a higher DIC than the isotopically heavier water, which we'll now refer to as the brine endmember. In figure $3 \mathrm{a}$ and $3 \mathrm{~b}$, we assume that isotopically heaviest opals record the $\delta^{18} \mathrm{O}$ composition of the brine endmember and that the $\delta^{13} \mathrm{C}$ composition matches marine carbon derived from the substrate $(-0 \%)$, the latter of which is recorded by sodic carbonates suspected of forming from brines in the Lewis Cliff area ${ }^{96}$. Under such assumptions the carbon ratio between meltwater and brine is 97:3 for PRR50489 (Fig. 3a) and 80:20 in MA113 (Fig. 3b), a result that is consistent with the calcite precipitation model presented above, whereby the addition of a carbon rich, oxidized meltwater, to a reduced or intermediate $\mathrm{CaCl}_{2}$ brine, triggers calcite precipitation. As shown in extended data figure 8 , the 
504 calcite data imply formation when there is $>30 \%$ of meltwater in the mixture. The array of calcite data can 505 also be fit by a mixing model that assumes an isotopically lighter carbon composition $\left(\delta^{13} \mathrm{C}=-15 \%\right)$. While 506 feasible, this is a less appealing solution, as a $\delta^{13} \mathrm{C}$ of $-15 \%$ does not match the composition of any specific 507 carbon source and would require a mixture of waters. The data presented here suggests that over the $\sim 100 \mathrm{ka}$ 508 of aggregate sample precipitation, there are two consistent endmember waters: a reduced brine that is locally 509 derived (star in second quadrant, Fig. 3), and an oxidized meltwater that is from the polar plateau (star in 510 third quadrant, Fig. 3). 


\section{References:}

1. Dutton, A. et al. Sea-level rise due to polar ice-sheet mass loss during past warm periods. Science (80-. ). 349, (2015).

2. Roberts, J. et al. Ocean forced variability of Totten Glacier mass loss. Geol. Soc. Spec. Publ. 461, 175-186 (2018).

3. Rintoul, S. R. et al. Ocean heat drives rapid basal melt of the totten ice shelf. Sci. Adv. 2, 1-6 (2016).

4. Joughin, I., Smith, B. E. \& Medley, B. Marine ice sheet collapse potentially under way for the thwaites glacier basin, West Antarctica. Science (80-. ). 344, 735-738 (2014).

5. Joughin, I., Alley, R. B. \& Holland, D. M. Ice-Sheet Response to Oceanic Forcing. Science (80-. ). 338, 1172-6 (2013).

6. Pollard, D. \& DeConto, R. M. Modelling West Antarctic ice sheet growth and collapse through the past five million years. Nature 458, 329-332 (2009).

7. DeConto, R. M. \& Pollard, D. Contribution of Antarctica to past and future sea-level rise. Nature 531, 591-597 (2016).

8. Mengel, M. \& Levermann, A. Ice plug prevents irreversible discharge from east Antarctica. Nat. Clim. Chang. 4, 451-455 (2014).

9. Reese, R., Gudmundsson, G. H., Levermann, A. \& Winkelmann, R. The far reach of ice-shelf thinning in Antarctica. Nat. Clim. Chang. 8, 53-57 (2018).

10. Golledge, N. R. et al. Antarctic contribution to meltwater pulse 1A from reduced Southern Ocean overturning. Nat. Commun. 5, 1-8 (2014).

11. Blasco, J., Tabone, I., Alvarez-Solas, J., Robinson, A. \& Montoya, M. The Antarctic Ice Sheet response to glacial millennial-scale variability. Clim. Past 15, 121-133 (2019).

12. Crowley, T. J. North Atlantic Deep Water Cools the Southern Hemisphere. Paleoceanography 7, 489-497 (1992).

13. Pedro, J. B. et al. Beyond the bipolar seesaw: Toward a process understanding of interhemispheric coupling. Quat. Sci. Rev. 192, 27-46 (2018).

14. Lu, J., Chen, G. \& Frierson, D. M. W. The position of the midlatitude storm track and eddy-driven westerlies in aquaplanet AGCMs. J. Atmos. Sci. 67, 3984-4000 (2010).

15. Schneider, T., Bischoff, T. \& Haug, G. H. Migrations and dynamics of the intertropical convergence zone. Nature 513, 45-53 (2014).

16. Marshall, J. \& Speer, K. Closure of the meridional overturning circulation through Southern Ocean upwelling. Nat. Geosci. 5, 171-180 (2012).

17. Anderson, H. J., Pedro, J. B., Bostock, H. C., Chase, Z. \& Noble, T. L. Compiled Southern Ocean sea surface temperatures correlate with Antarctic Isotope Maxima. Quat. Sci. Rev. 255, 106821 (2021).

18. Weber, M. E., Golledge, N. R., Fogwill, C. J., Turney, C. S. M. \& Thomas, Z. A. Decadal-scale onset and termination of Antarctic ice-mass loss during the last deglaciation. Nat. Commun. 12, (2021).

19. Fretwell, P. et al. Bedmap2: Improved ice bed, surface and thickness datasets for Antarctica. Cryosphere 7, 375-393 (2013).

20. Bohm, E. et al. Strong and deep Atlantic meridional overturning circulation during the last glacial cycle. Nature 517, 73-76 (2015).

21. Ai, X. E. et al. Southern Ocean upwelling, Earth's obliquity, and glacial-interglacial atmospheric CO2 change. 1, 1348-1352 (2020).

22. Weber, M. E. et al. Millennial-scale variability in Antarctic ice-sheet discharge during the last deglaciation. Nature 510, 134-138 (2014).

23. Fogwill, C. J., Turney, C. S. M., Golledge, N. R., Etheridge, D. M. \& Rubino, M. Antarctic ice sheet discharge driven by atmosphere-ocean feedbacks at the Last Glacial Termination. Nature 110 (2017). doi:10.1038/srep39979

24. Turney, C. S. M. et al. Early Last Interglacial ocean warming drove substantial ice mass loss from 
Antarctica. Proc. Natl. Acad. Sci. U. S. A. 117, 3996-4006 (2020).

25. Kassab, C. M. et al. Formation and evolution of an extensive blue ice moraine in central Transantarctic Mountains, Antarctica. J. Glaciol. 66, 49-60 (2019).

26. Keller, B. A Bayesian framework for integrated eruption age and age-depth modelling. (2020). doi:doi:10.17605/OSF.IO/TQX3F

27. Members, W. D. P. Precise interpolar phasing of abrupt climate change during the last ice age. Nature 520, 661-665 (2015).

28. Jouzel, J. et al. Orbital and millennial antarctic climate variability over the past 800,000 years. Science (80-. ). 317, 793-796 (2007).

29. Andersen, K. K. et al. High-resolution record of Northern Hemisphere climate extending into the last interglacial period. Nature 431, 147-151 (2004).

30. Aharon, P. Oxygen, carbon and U-series isotopes of aragonites from Vestfold Hills, Antarctica: Clues to geochemical processes in subglacial environments. Geochim. Cosmochim. Acta 52, 23212331 (1988).

31. Graly, J. A., Licht, K. J., Kassab, C. M., Bird, B. W. \& Kaplan, M. R. Warm-based basal sediment entrainment and far-field Pleistocene origin evidenced in central Transantarctic blue ice through stable isotopes and internal structures. J. Glaciol. 64, 185-196 (2018).

32. Landais, A., Barkan, E. \& Luz, B. Record of $\delta 18 \mathrm{O}$ and $17 \mathrm{O}$-excess in ice from Vostok Antarctica during the last 150,000 years. Geophys. Res. Lett. 35, 1-5 (2008).

33. Masson-Delmotte, V. et al. A review of antarctic surface snow isotopic composition: Observations, atmospheric circulation, and isotopic modeling. J. Clim. 21, 3359-3387 (2008).

34. German, C. R. \& Elderfield, H. Application of the Ce anomaly as a paleoredox indicator: The ground rules. Paleoceanography 5, 823-833 (1990).

35. Yan, Y. et al. Two-million-year-old snapshots of atmospheric gases from Antarctic ice. Nature 574, (2019).

36. Murray, A. E. et al. Microbial life at $-13^{\circ} \mathrm{C}$ in the brine of an ice-sealed Antarctic lake. Proc. Natl. Acad. Sci. U. S. A. 109, 20626-20631 (2012).

37. Doran, P. T., Kenig, F., Knoepfle, J. L., Mikucki, J. A. \& Berry Lyons, W. Radiocarbon distribution and the effect of legacy in lakes of the McMurdo Dry Valleys, Antarctica. Limnol. Oceanogr. 59, 811-826 (2014).

38. McNutt, R. H., Frape, S. K., Fritz, P., Jones, M. G. \& MacDonald, I. M. The $87 \mathrm{Sr} 86 \mathrm{Sr}$ values of Canadian Shield brines and fracture minerals with applications to groundwater mixing, fracture history, and geochronology. Geochim. Cosmochim. Acta 54, 205-215 (1990).

39. Toner, J. D. \& Sletten, R. S. The formation of Ca-Cl-rich groundwaters in the Dry Valleys of Antarctica : Field measurements and modeling of reactive transport. Geochim. Cosmochim. Acta 110, 84-105 (2013).

40. Lyons, W. B. et al. The Geochemistry of Englacial Brine From Taylor Glacier, Antarctica. $J$. Geophys. Res. Biogeosciences 124, 633-648 (2019).

41. Lyons, W. B. et al. The carbon stable isotope biogeochemistry of streams, Taylor Valley, Antarctica. Appl. Geochemistry 32, 26-36 (2013).

42. Christner, B. C. et al. A microbial ecosystem beneath the West Antarctic ice sheet. Nature 512, 310-313 (2014).

43. Goodwin, I. D. The nature and origin of a jokulhlaup near Casey Station, Antarctica. J. Glaciol. 34, 95-101 (1988).

44. Goodwin, I. D. et al. Modern to Glacial age subglacial meltwater drainage at Law Dome, coastal East Antarctica from topography, sediments and jökulhlaup observations. Geol. Soc. Spec. Publ. 461, 215-230 (2018).

45. Frisia, S. et al. The influence of Antarctic subglacial volcanism on the global iron cycle during the Last Glacial Maximum. Nat. Commun. 8, 1-9 (2017).

46. Parkhurst, D. L. \& Appelo, C. a. J. Description of Input and Examples for PHREEQC Version 3 - A Computer Program for Speciation, Batch-Reaction, One-Dimensional Transport, and 
Inverse Geochemical Calculations. U.S. Geological Survey Techniques and Methods, book 6, chapter A43, 497 p. U.S. Geol. Surv. Tech. Methods, B. 6, chapter A43 6-43A (2013).

47. Hallet, B. Deposits formed by subglacial precipitation of CaCO 3. Bull. Geol. Soc. Am. 87, $1003-$ 1015 (1976).

48. Killawee, J. A., Fairchild, I. J., Tison, J. L., Janssens, L. \& Lorrain, R. Segregation of solutes and gases in experimental freezing of dilute solutions: Implications for natural glacial systems. Geochim. Cosmochim. Acta 62, 3637-3655 (1998).

49. Buizert, C. et al. Abrupt ice-age shifts in southern westerly winds and Antarctic climate forced from the north. Nature 563, 681-684 (2018).

50. Bahr, D. B., Pfeffer, W. T. \& Kasar, G. A review of volume-area scaling of glaciers. Rev. Geophys. 53, 95-140 (2014).

51. Pattyn, F. Antarctic subglacial conditions inferred from a hybrid ice sheet / ice stream model. Earth Planet. Sci. Lett. 295, 451-461 (2010).

52. Van Liefferinge, B. \& Pattyn, F. Using ice-flow models to evaluate potential sites of million yearold ice in Antarctica. Clim. Past 9, 2335-2345 (2013).

53. Clark, P. U. Subglacial Sediment Dispersal and till Composition. J. Geol. 95, 527-541 (1987).

54. Sugden, D. E. Glacial Erosion by the Laurentide Ice Sheet. J. Glaciol. 20, 367-391 (1978).

55. Coren, F., Delisle, G. \& Sterzai, P. Ice dynamics of the Allan Hills meteorite concentration sites revealed by satellite aperture radar interferometry. Meteorit. Planet. Sci. 38, 1319-1330 (2003).

56. Schoof, C. Ice sheet grounding line dynamics: Steady states, stability, and hysteresis. J. Geophys. Res. Earth Surf. 112, 1-19 (2007).

57. Grant, K. M. et al. Sea-level variability over five glacial cycles. Nat. Commun. 5, (2014).

58. Golledge, N. R., Marsh, O. J., Rack, W., Braaten, D. \& Jones, R. S. Basal conditions of two Transantarctic Mountains outlet glaciers from observation-constrained diagnostic modelling. $J$. Glaciol. 60, 855-866 (2014).

59. Bell, R. E., Studinger, M., Shuman, C. A., Fahnestock, M. A. \& Joughin, I. Large subglacial lakes in East Antarctica at the onset of fast-flowing ice streams. Nature 445, 904-907 (2007).

60. Stearns, L. A., Smith, B. E. \& Hamilton, G. S. Increased flow speed on a large east antarctic outlet glacier caused by subglacial floods. Nat. Geosci. 1, 827-831 (2008).

61. Creyts, T. T. \& Schoof, C. G. Drainage through subglacial water sheets. J. Geophys. Res. Earth Surf. 114, 1-18 (2009).

62. Mack, D. J. movcorr(x, y, k, varargin): Compute windowed correlation coefficient. (2022).

63. Coplen, T. B. et al. New Guidelines for 813 C Measurements. Anal. Chem. 78, 2439-2441 (2006).

64. Ostermann, D. R. \& Curry, W. B. Calibration of stable isotopic data: An enriched $\delta 18 \mathrm{O}$ standard used for source gas mixing detection and correction. Paleoceanography 15, 353-360 (2000).

65. Clayton, R. N. \& Mayeda, T. K. The use of bromine pentafluoride in the extraction of oxygen from oxides and silicates for isotopic analysis. Geochim. Cosmochim. Acta 27, 43-52 (1963).

66. Wostbrock, J. A. G. et al. Calibration and application of silica-water triple oxygen isotope thermometry to geothermal systems in Iceland and Chile. Geochim. Cosmochim. Acta 234, 84-97 (2018).

67. Chamberlain, C. P. et al. Triple oxygen isotopes of meteoric hydrothermal systems - implications for palaeoaltimetry. Geochemical Perspect. Lett. 15, 6-9 (2020).

68. Ibarra, D. E., Kukla, T., Methner, K. A., Mulch, A. \& Chamberlain, C. P. Reconstructing Past Elevations From Triple Oxygen Isotopes of Lacustrine Chert: Application to the Eocene Nevadaplano, Elko Basin, Nevada, United States. Front. Earth Sci. 9, 1-19 (2021).

69. Ibarra, D. E. et al. Triple oxygen isotope systematics of diagenetic recrystallization of diatom opal-A to opal-CT to microquartz in deep sea sediments. Geochim. Cosmochim. Acta (2021). doi:10.1016/j.gca.2021.11.027

70. Sharp, Z. D. \& Wostbrock, J. A. G. Standardization for the Triple Oxygen Isotope System: Waters, Silicates, Carbonates, Air, and Sulfates. Rev. Mineral. Geochemistry 86, 179-196 (2021).

71. Menicucci, A. J., Matthews, J. A. \& Spero, H. J. Oxygen isotope analyses of biogenic opal and 
701

702

703

704

705

706

707

708

709

710

711

712

713

714

715

quartz using a novel microfluorination technique. Rapid Commun. Mass Spectrom. 27, 1873-1881 (2013).

72. Chapligin, B. et al. Inter-laboratory comparison of oxygen isotope compositions from biogenic silica. Geochim. Cosmochim. Acta 75, $7242-7256$ (2011).

73. Paton, C., Hellstrom, J., Paul, B., Woodhead, J. \& Hergtb, J. Iolite : Freeware for the visualisation and processing of mass spectrometric data. J. Anal. At. Spectrom. 26, 2508-2518 (2011).

74. Marion, G. M., Mironenko, M. V. \& Roberts, M. W. FREZCHEM: A geochemical model for cold aqueous solutions. Comput. Geosci. 36, 10-15 (2010).

75. Iler, R. K. The Chemistry of Silica: Solubility, Polymerization, Colloid and Surface Properties, and Biochemistry. John Wiley and Sons Ltd., New York. (1979).

76. Hawkings, J. R. et al. Enhanced trace element mobilization by Earth's ice sheets. Proc. Natl. Acad. Sci. 1-12 (2020). doi:10.1073/pnas.2014378117

77. Green, W. J. \& Canfield, D. E. Geochemistry of the Onyx River (Wright Valley, Antarctica) and its role in the chemical evolution of Lake Vanda. Geochim. Cosmochim. Acta 48, 2457-2467 (1984).

78. Tréguer, P. et al. The silica balance in the world ocean: A reestimate. Science (80-. ). 268, 375379 (1995).

79. Frape, S. K., Fritz, P. \& McNutt, R. H. Water-rock interaction and chemistry of groundwaters from the Canadian Shield. Geochim. Cosmochim. Acta 48, 1617-1627 (1984).

80. Bell, R. E. et al. Widespread Persistent Thickening of the East Antarctic Ice Sheet by Freezing from the Base. Science (80-. ). 331, 1592-1596 (2011).

81. Hallet, B. Deposits Formed by Subglacial Precipitation of CaCO3. Geol. Soc. Am. Bull. 87, 10031015 (1976).

82. Wilson, A. T. Geochemical problems of the Antarctic dry areas. Nature 280, 205-208 (1979).

83. Webster, J. G., Goguel, R. L. \& Pond, D. J. Anions and alkali metals in Lake Vanda, Don Juan Pond, and the Onyx River : Further indications of brine origin. 154-156 (1988).

84. Cartwright, K. \& Harris, H. J. H. Hydrogeology of the Dry Valley region, Antarctica. Am. Geophys. Union, Antarct. Res. Ser. 33, 193-214 (1981).

85. Levy, J. S., Fountain, A. G., Welch, K. A. \& Lyons, W. B. Hypersaline 'wet patches' in Taylor Valley, Antarctica. Geophys. Res. Lett. 39, 1-5 (2012).

86. Harris, H. J. H. \& Cartwright, K. Hydrology of the Don Juan Basin, Wright Valley, Antarctica. Antarct. Res. Ser. 33, 162-184 (1981).

87. Angino, E. E. \& Armitage, K. B. A Geochemical Study of Lakes Bonney and Vanda, Victoria Land, Antarctica. J. Geol. 71, 89-95 (1963).

88. Healy, M., Webster-Brown, J. G., Brown, K. L. \& Lane, V. Chemistry and stratification of Antarctic meltwater ponds II: Inland ponds in the McMurdo Dry Valleys, Victoria Land. Antarct. Sci. 18, 525-533 (2006).

89. Lyons, W. B. et al. The geochemistry of upland ponds, Taylor Valley, Antarctica. Antarct. Sci. 24, 3-14 (2012).

90. Carlson, C. A., Phillips, F. M., Elmore, D. \& Bentley, H. W. Chlorine-36 tracing of salinity sources in the Dry Valleys of Victoria Land, Antarctica. Geochim. Cosmochim. Acta 54, 311-318 (1990).

91. Dickson, J. L., Head, J. W., Levy, J. S. \& Marchant, D. R. Don Juan Pond, Antarctica: Nearsurface $\mathrm{CaCl}$ 2-brine feeding Earth's most saline lake and implications for Mars. Sci. Rep. 3, 1-8 (2013).

92. Toner, J. D., Catling, D. C. \& Sletten, R. S. The geochemistry of Don Juan Pond: Evidence for a deep groundwater flow system in Wright Valley, Antarctica. Earth Planet. Sci. Lett. 474, 190-197 (2017).

93. Nurmi, P. A., Kukkonen, I. T. \& Lahermo, P. W. Geochemistry and origin of saline groundwaters in the Fennoscandian Shield. Appl. Geochemistry 3, 185-203 (1988).

94. Kim, S. T. \& O’Neil, J. R. Equilibrium and nonequilibrium oxygen isotope effects in synthetic 
carbonates. Geochim. Cosmochim. Acta 61, 3461-3475 (1997).

95. Sharp, Z. D. et al. A calibration of the triple oxygen isotope fractionation in the $\mathrm{SiO} 2-\mathrm{H} 2 \mathrm{O}$ system and applications to natural samples. Geochim. Cosmochim. Acta 186, 105-119 (2016).

96. Fitzpatrick, J. J., Muhs, D. R. \& Jull, A. J. T. Saline Minerals in the Lewis Cliff Ice Tongue, Buckley Island Quadrangle, Antarctica. Contrib. to Antarct. Res. I 50, 57-69 (1990).

97. Veres, D. et al. The Antarctic ice core chronology (AICC2012): An optimized multi-parameter and multi-site dating approach for the last 120 thousand years. Clim. Past 9, 1733-1748 (2013).

98. Steig, E. J. et al. Wisonsinan and Holocence climate history from an ice core at Taylor Dome, western Ross embayment, Antarctica. Geogr. Ann. Ser. A Phys. Geogr. 82, 213-235 (2000).

99. Grootes, P. M. et al. The Taylor Dome Antarctic 180 record and globally synchronous changes in climate. Quat. Res. 56, 289-298 (2001).

100. Phillips, D. L. \& Koch, P. L. Incorporating concentration dependence in stable isotope mixing models. Oecologia 130, 114-125 (2002). 

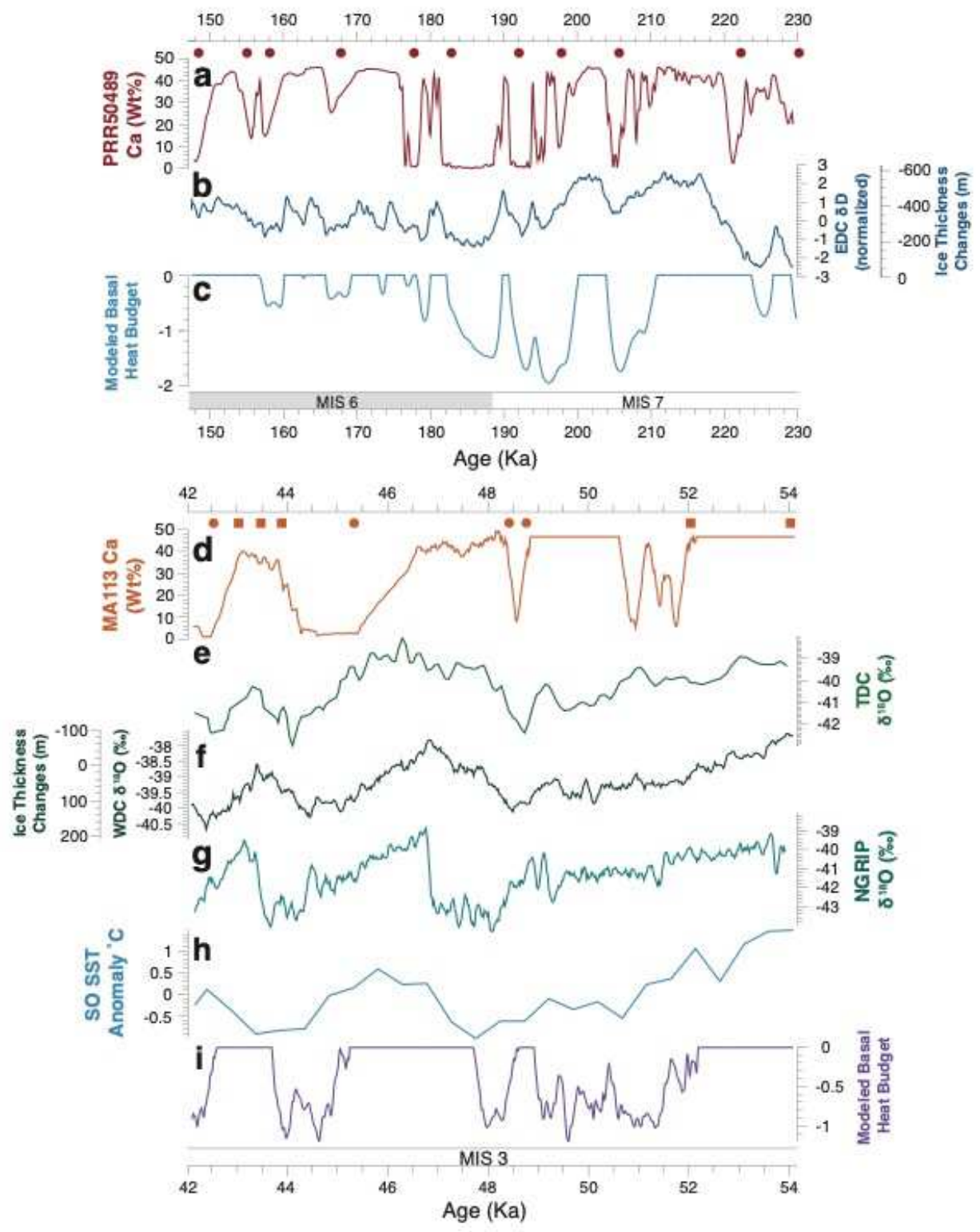

Fig. 1 Comparison of precipitate mineralogy with climate records. a. Subglacial precipitate sample PRR50489 Ca concentration. b. $\delta$ D measured in EPICA Dome C Ice Core (EDC) ${ }^{28,97}$. EDC record is detrended and converted to a z-score by zero-mean normalization to eliminate orbital trends. c. Reduced complexity model output of basal heat budget over the time frame of sample PRR50489 in units of mm/year of equivalent basal freezing rate. Negative values indicate freezing. Positive values correspond to basal melting and are truncated at $0 \mathrm{~mm} / \mathrm{yr}$ because we consider any positive values to be sufficient to maintain hydrologic connectivity to regional subglacial waters. d. Subglacial precipitate sample MA113 Ca 
818 concentration. e. $\delta^{18} \mathrm{O}$ measured in Taylor Dome Ice Core (TDC) ${ }^{98,99}$ f. $\delta^{18} \mathrm{O}$ measured in West Antarctic 819 Divide Ice Core (WDC) ${ }^{27}$. g. $\delta^{18} \mathrm{O}$ measured in Northern Greenland Ice Core Project (NGRIP) ${ }^{29}$. h. 820 Southern Ocean sea surface temperature anomalies from stacked drill core records ${ }^{17}$. f. as in c. for sample 821 MA113. Positive values correspond to basal melt and are truncated at $0 \mathrm{~mm} /$ year. High values in precipitate 822 records represent calcite precipitation; low values represent opal precipitation. Markers above a and $\mathbf{d}$ show 823 the location of dated layers; square markers represent calcite ages; circles represent opal ages. Records in $824 \mathbf{b}, \mathbf{g}$, and $\mathbf{h}$ are synchronized to AICC2012 chronology; the record in $\mathbf{f}$ is synchronized WD2014 chronology, 825 the record in e is visually tuned to match the record in f. Isotope ratios are on the VSMOW (Vienna Standard 826 Mean Ocean Water) scale. Marine Isotope substages are marked in grey and white and are labeled. Forcing 827 for reduced complexity model of ice thermodynamics is provided by ice thickness changes at the Foothills 828 of the TAM, which are parameterized as a linear function of the ice core isotopic record. The magnitude 829 and scale of these thickness changes is shown on the right $y$-axis of $\mathbf{b}$. and $\mathbf{f}$. 


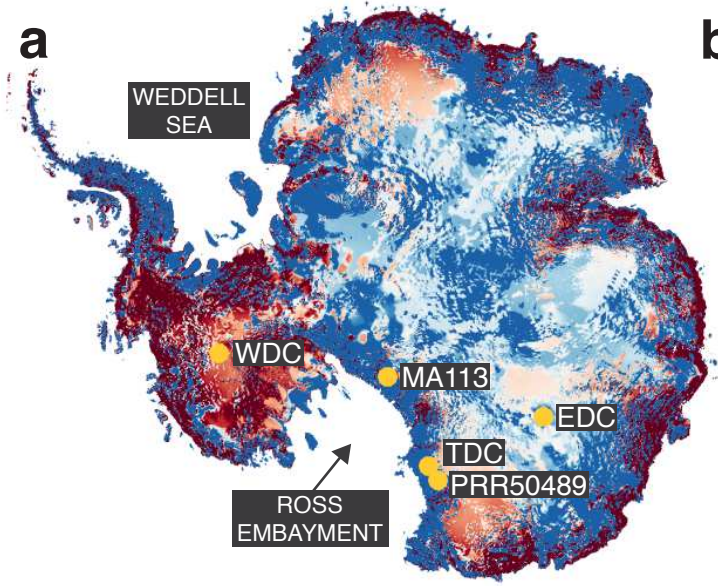

b

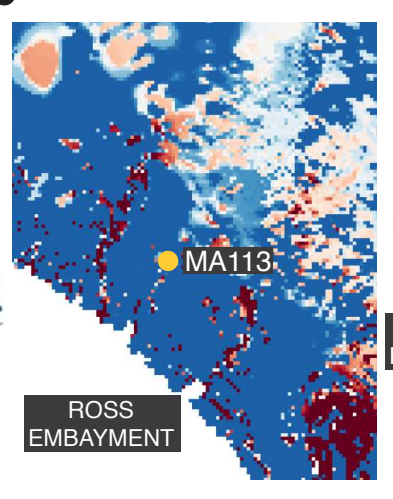

C

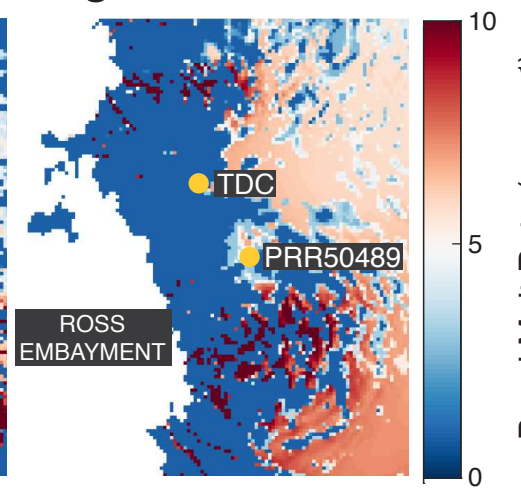

Fig. 2 Antarctic Mean Basal Melt Rate. a. Map of estimated modern mean basal melt rate ${ }^{52}$ truncated at $^{2}$ $10 \mathrm{~mm} \mathrm{yr}^{-1}$. Dark blue areas are frozen at the bed, white to red areas experience basal melting. b. Map zoomed in to show basal melt rate near location of MA113. c. Map zoomed in to show basal melt rate near location of. PRR50489. Markers indicate locations of spectra shown in figure 2. 

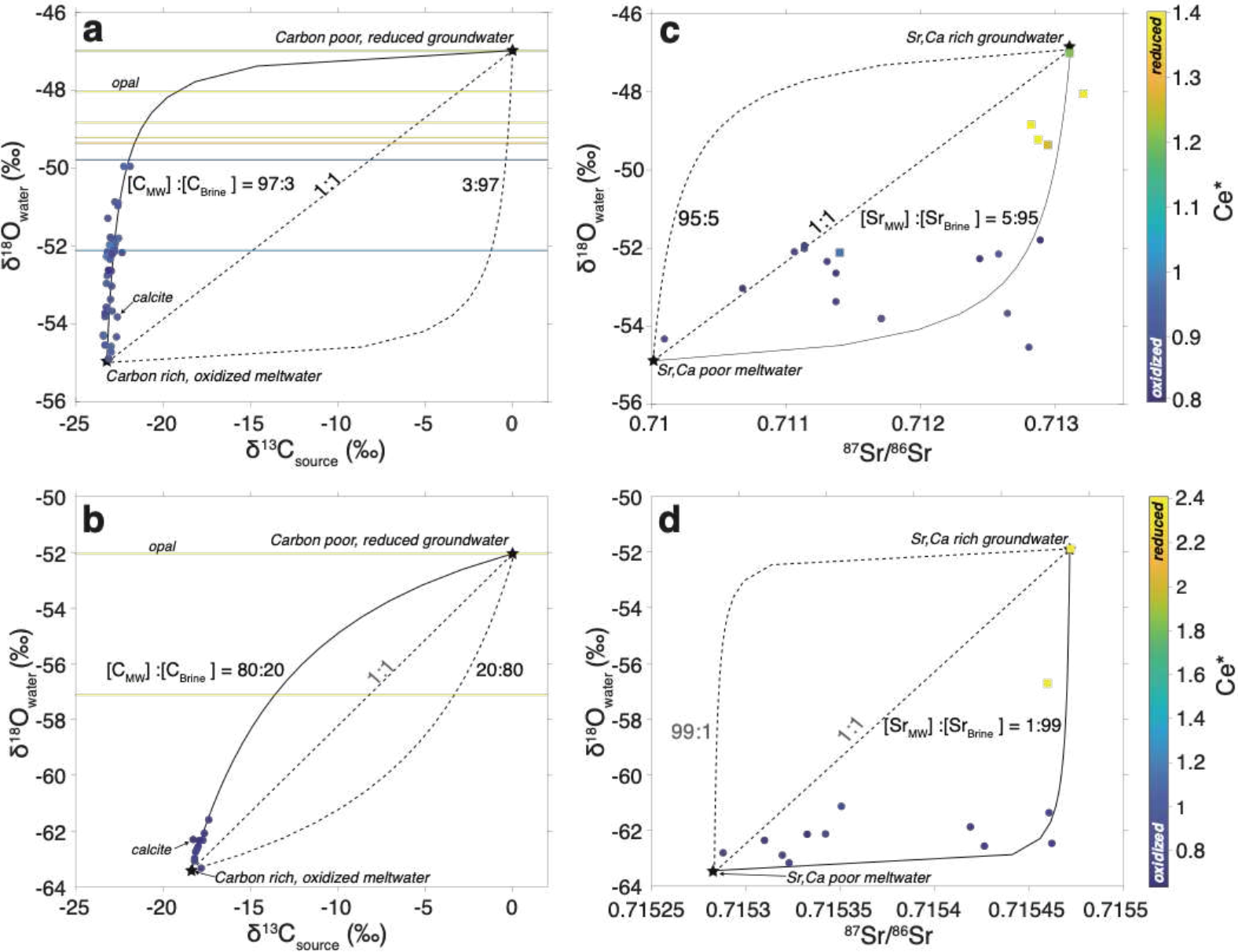

Fig. 3 | Stable isotope mixing models for precipitates PRR50489 and MA113. a. $\delta^{18} \mathrm{O}$ of the precipitating fluid versus $\delta^{13} \mathrm{C}$ composition of the $\mathrm{C}$ source, plotted for PRR50489 calcite (markers) and opal (horizontal lines). Endmembers (stars) include an opal precipitating fluid that is a carbon poor, reduced brine; and a calcite precipitating fluid that is a carbon rich, oxidizing meltwater. Solid curved line represents mixing model between the two endmembers ${ }^{100}$. To fit calcite data, mixing model requires meltwater to have a total carbon concentration 40-fold higher than brine. b. As in a, but data are from sample MA113. To fit calcite data, mixing model requires meltwater to have a total carbon concentration 5-fold higher than brine. c. $\delta^{18} \mathrm{O}$ of the precipitating fluid versus ${ }^{87} \mathrm{Sr} /{ }^{86} \mathrm{Sr}$ composition of the $\mathrm{Sr}$ source, plotted for PRR50489 calcite (circles) and opal (squares). To fit data, mixing model requires meltwater to have a total strontium concentration 20-fold higher than brine d. As is c, but data are from MA113. To fit data, mixing model requires meltwater to have a total strontium concentration 50-fold higher than brine. Dashed lines represent mixing models with different $\mathrm{C}$ or Sr ratios. All data are color coded by Ce* value, with blue being the lowest, most oxidizing values, and yellow being the highest, most reducing values. Oxygen isotopic compositions corrected to water compositions assuming equilibrium fractionation during calcite formation and a formation of $0^{\circ} \mathrm{C}$. 


\section{Supplementary Files}

This is a list of supplementary files associated with this preprint. Click to download.

- ExtendedDataTable3.xlsx

- ExtendedDataFigures.pdf

- ExtendedDataTable4.xlsx

- ExtendedDataTable2.xlsx

- ExtendedDataTable1.xlsx

- SupplementaryText.pdf 